\title{
Manajemen Pemasaran dalam Mempercepat Penyerapan Lulusan dalam Satuan Pendidikan Kejuruan
}

\author{
Dinar Ika Safitri*, Maisyaroh, Ahmad Nurabadi \\ Universitas Negeri Malang, Jl. Semarang No. 5 Malang, Jawa Timur, Indonesia \\ *Penulis korespondensi, Surel: dinarikasafitri@gmail.com
}

Paper received: 25-8-2021; revised: 8-9-2021; accepted: 15-9-2021

\begin{abstract}
This study aims to describe the planning, organizing, implementing, and evaluating the marketing of graduates in vocational education units, as well as supporting factors and inhibiting marketing of graduates in vocational education units. This study used a qualitative model with a case study design. Data collection uses interviews, observation, and documentation. In analyzing data using data collection, data reduction, data presentation, and conclusion drawing. The results of the study show that graduates from these schools are absorbed into the world of work even before they graduate from school and have obtained jobs. This is supported by good marketing management starting from planning, organizing, implementing, and evaluating the marketing of graduates. The obstacle is when the parents of students do not want their children to get jobs in long distances.
\end{abstract}

Keywords: management; markerting of graduates; absorption of graduates

\begin{abstract}
Abstrak
Penelitian ini bertujuan untuk mendeskripsikan perencanaan, pengorganisasian, pelaksanaan, dan evaluasi pemasaran lulusan dalam satuan pendidikan kejuruan, serta faktor pendukung dan penghambat pemasaran lulusan di satuan pendidikan kejuruan. Penelitian ini menggunakan model kualitatif dengan desain studi kasus. Pengumpulan data menggunakan wawancara, observasi, dan dokumentasi. Dalam menganalisis data menggunakan pengumpulan data, reduksi data, penyajian data, dan penarikan kesimpulan. Hasil penelitian menunjukkan bahwa lulusan dari sekolah tersebut banyak terserap ke dunia kerja bahkan sebelum mereka lulus dari sekolah sudah memperoleh pekerjaan. Hal tersebut didukung dengan manajemen pemasaran yang baik mulai dari perencanaan, pengorganisasian, pelaksanaan, dan evaluasi pemasaran lulusan. Kendalanya adalah ketika orangtua peserta didik tidak ingin anaknya memperoleh pekerjaan dengan jarak yang jauh.
\end{abstract}

Kata kunci: manajemen; pemasaran lulusan; penyerapan lulusan

\section{Pendahuluan}

Kompetisi antar sekolah semakin lama semakin ketat dengan adanya upaya kreatif penyelenggaraan pendidikan untuk menggali keunikan dan keunggulan sekolahnya untuk dapat diamati dan dibutuhkan oleh pelanggan jasa pendidikan. Aktivitas pemasaran jasa pendidikan sebelum atau sesudah lulus sekolah kini semakin gencar dilakukan oleh pihak sekolah agar para lulusannya bisa langsung bekerja dengan dibekali keterampilanketerampilan yang didapat di sekolah. Sekolah Menengah Kejuruan (SMK) merupakan sekolah yang menciptakan peserta didiknya untuk siap bekerja. Peserta didik yang menempuh pendidikan di SMK dibekali oleh pengetahuan, keterampilan, dan keahlian sesuai dengan bidang yang diinginkan untuk diimplementasikan sebelum dan setelah lulus dari sekolah. Peserta didik juga dibekali untuk membuat usahanya sendiri dan membuka lapangan pekerjaan untuk yang lainnya. 
Peraturan Pemerintah Nomor 19 Tahun 2005 Pasal 26 tentang Standar Nasional Pendidikan menyatakan tujuan utama SMK yaitu "meningkatkan kecerdasan, pengetahuan, kepribadian, akhlak mulia, serta keterampilan untuk hidup mandiri dan mengikuti pendidikan lebih lanjut sesuai dengan kejuruannya". Dalam manajemen pemasaran lulusan di satuan pendidikan kejuruan memiliki berbagai macam strategi sehingga dapat bekerjasama dengan banyak Dunia Usaha dan Dunia Industri (DUDI) dan juga memiliki relasi untuk mengirimkan peserta didik melakukan prakerin dan banyak peserta didik yang belum lulus tetapi sudah direkrut di tempatnya prakerin. Menurut Benty \& Gunawan (2015) menyatakan bahwa pemasaran merupakan kegiatan transaksional untuk meningkatkan kebutuhan calon konsumen dengan mengeluarkan imbalan yang disepakati. Dalam kaitannya dengan pemasaran lulusan, maka pemasaran merupakan proses memasarkan lulusan agar calon alumni dan alumni cepat terserap kerja. Menurut Abdullah \& Tantri (2003) menjelaskan bahwa tujuan pemasaran adalah untuk memenuhi kebutuhan dan keinginan dari pelanggan yang menjadi sasaran pihak produsen. Dalam dunia pendidikan dapat dijelaskan bahwa tujuan pemasaran lulusan adalah untuk memasarkan calon alumni kepada mitra kerja sekolah agar langsung terserap ke dunia kerja. Peserta didik yang telah selesai menempuh pendidikannya bisa disalurkan ke mitra kerja yang kerjasama dengan sekolah. Badan Pusat Statistik mencatat tingkat pengangguran terbuka di Kota Malang mencapai 6,79\% dan merupakan tingkat pengangguran tertinggi di Jawa Timur. Jumlah pengangguran terbuka di Kota Malang sebanyak 30.898 jiwa dari total 454.849 jiwa angkatan kerja pada tahun 2018 berdasarkan hasil dari survei angkatan kerja nasional. Jumlah pengangguran didominasi lulusan dari SMA dan SMK yang mencapai $42,11 \%$ dan perguruan tinggi mencapai 32,83\%. Sedangkan untuk lulusan SMP sekitar 6,57\% dan lulusan SD sekitar 18,49\% (liputan6.com, 31 Januari 2019).

Pemasaran lulusan di SMK PGRI 3 Kota Malang dilakukan sebelum peserta didik lulus sehingga ketika peserta didik lulus mereka sudah memperoleh pekerjaan. Pemasaran lulusan ditangani oleh tim yang dibentuk oleh sekolah yaitu tim BKI (Bidang Kerjasama Industri). Menurut Raharjo (2009) menjelaskan keberadaan BKK di sekolah kejuruan bertugas membantu sekolah dalam menginformasikan dan mempromosikan profil kemampuan yang dimiliki tamatan sekaligus mencatat, mendata para alumni untuk selanjutnya memasarkan/menawarkan kepada industri untuk mengisi pekerjaan sesuai dengan kesempatan yang ada. Di sekolah terdapat kelas industri yaitu kelas yang di dalamnya adalah peserta didik yang dipilih langsung oleh mitra kerja sekolah. Menurut Slamet, dkk (2017) menyatakan bahwa kelas industri merupakan program kerjasama antara industri dengan satuan pendidikan kejuruan dalam mengintegrasikan pembelajaran di sekolah dengan dunia industri. Angka keterserapan lulusan di sekolah sangat tinggi kisaran 80-90\% peserta didik sudah bekerja selama periode 1 tahun setelah lulus pada angkatan 2018. Sedangkan untuk peserta didik lulusan 2019 sebelum mereka lulus dari sekolah sekitar 40-60\% sudah memperoleh pekerjaan. Berdasarkan uraian di atas, tujuan penelitian ini adalah mendeskripsikan mengenai perencanaan, pengorganisasian, pelaksanaan, dan evaluasi pemasaran lulusan sebagai upaya mempercepat penyerapan lulusan dalam dunia kerja. Serta faktor yang mendukung dan menghambat pemasaran lulusan di SMK PGRI 3 Kota Malang.

\section{Metode}

Penelitian ini menggunakan jenis pendekatan kualitatif dan menggunakan jenis penelitian studi kasus yang akan mendeskripsikan fokus penelitian. Lokasi penelitian bertempat di SMK PGRI 3 Kota Malang yang beralamatkan di Jalan Raya Tlogomas Gang 9 No. 29 Tlogomas, Lowokwaru, Kota Malang. Teknik pengumpulan data yang digunakan adalah 
wawancara, observasi, dan dokumentasi untuk mengetahui perencanaan pemasaran lulusan, pengorganisasian pemasaran lulusan, pelaksanaan pemasaran lulusan, dan evaluasi pemasaran lulusan serta faktor yang mendukung dan menghambat pemasaran lulusan. Selanjutnya, tahapan dalam analisis data yang dilakukan peneliti sesuai dengan model analisis data Miles dan Huberman yaitu pengumpulan data, reduksi data, penyajian data, dan penarikan kesimpulan. Data yang telah diperoleh akan diperiksa dulu keabsahannya dengan menggunakan (1) triangulasi sumber yaitu peneliti melakukan wawancara dengan tim BKI bagian pengembangan alumni, tim BKI bagian prakerin, kepala bidang jurusan otomotif, guru wali, alumni, dan salah satu mitra kerja sekolah untuk kemudian membandingkan jawaban dari informan tersebut, selain itu peneliti juga menggunakan triangulasi teknik dengan membandingkan informasi menggunakan teknik wawancara, observasi, dan dokumentasi; (2) kecukupan referensi sebagai bahan pendukung dan pembuktian data yang telah ditemukan agar data yang diperoleh lebih dipercaya misalnya berupa transkrip wawancara, catatan lapangan, foto- foto, dan perekam suara.

\section{Hasil dan Pembahasan}

\subsection{Hasil Penelitian}

\subsubsection{Perencanaan Pemasaran Lulusan dalam Satuan Pendidikan Kejuruan}

Perencanaan merupakan hal yang penting dalam suatu manajemen. Perencanaan menjadi tahapan pertama dalam melakukan sesuatu, perencanaan harus sesuai dengan tujuan yang diinginkan oleh suatu organisasi. Perencanaan pemasaran lulusan dilakukan semaksimal mungkin sehingga ketika peserta didik belum lulus atau sudah lulus mereka mudah diterima oleh perusahaan-perusahaan yang bekerjasama dengan sekolah. Perencanaan pemasaran lulusan agar lulusannya memiliki potensi yang baik dan bisa langsung terserap ke dunia kerja tidak terlepas dari bagaimana pihak sekolah mengasah kemampuan, pengetahuan, serta keterampilan peserta didik sehingga mereka dapat mengaplikasikannya di dunia kerja. Perencanaan pemasaran di sekolah dimulai ketika peserta didik dan orangtua peserta didik menandatangani surat pernyataan pilihan yang menjelaskan pilihan peserta didik ketika sudah lulus dari sekolah. Pilihan dari surat pernyataan tersebut adalah peserta didik ingin bekerja, kuliah, masuk TNI/Polri, atau berwirausaha. Dalam surat pernyataan berisi pernyataan pemilihan setelah lulus yang harus ditandatangani oleh peserta didik, orangtua peserta didik, guru walinya, dan diketahui oleh kepala sekolah. Surat pernyataan tersebut adalah semacam surat perjanjian yang dilakukan oleh pihak sekolah dan orangtua peserta didik bahwa ketika mereka memilih bekerja dan setelah mereka lulus mereka akan dicarikan pekerjaan oleh sekolah.

Di sisi lain, perencanaan pemasaran lulusan juga melibatkan guru. Guru berperan sangat penting untuk melatih soft skill peserta didik sehingga ketika mereka prakerin maupun sudah lulus dari sekolah dan memasuki dunia kerja sudah memperoleh ilmu bahkan pengalaman bekerja. Terdapat juga pembekalan-pembekalan yang dilakukan sekolah setelah mereka mengisi surat pernyataan yang sudah disediakan. Pembekalan tersebut dimaksudkan agar mereka memilih pilihannya akan semakin menguasai bagaimana cara mereka bisa menjalankan pilihan mereka dengan maksimal. BKI juga melakukan promosi kepada perusahaan rekanan sekolah agar dapat menyalurkan calon alumni dan alumninya ke perusahaan tersebut. Berdasarkan uraian tersebut dapat disimpulkan bahwa perencanaan 
pemasaran lulusan adalah pemetaan peserta didik yang akan lulus untuk memilih kerja, kuliah, masuk TNI/Polri, dan berwirausaha. Kedua, pelatihan soft skill dan pembekalan kepada peserta didik. Selanjutnya, melakukan promosi kepada perusahaan rekanan perusahaan sehingga peserta didik mudah terserap ke dunia kerja.

\subsubsection{Pengorganisasian Pemasaran Lulusan dalam Satuan Pendidikan Kejuruan}

Suatu manajemen memerlukan segala sumber daya yang digunakan untuk mencapai tujuan organisasi. Pengoraganisian menjadi satu hal yang penting agar masing-masing anggota dapat mengerti tugas pokok dan fungsi dari pekerjaan mereka. Dalam pemasaran yang dilakukan sekolah tidak terlepas dari peran BKI (Bidang Kerja Industri), BKI merupakan tim yang dibentuk kepala sekolah untuk menangani pemasaran peserta didik sebelum dan sesudah lulus dari sekolah dan menangani prakerin peserta didik.. Melalui BKI peserta didik tidak lagi mencari pekerjaan sendiri setelah lulus tetapi akan dicarikan oleh sekolah. Dengan adanya tim BKI yang mencarikan pekerjaan untuk calon lulusan dan alumninya maka akan mempercepat penyerapan lulusan dalam dunia kerja karena peserta didik akan mendapatkan pekerjaan sesuai dengan kemampuannya. Sekolah tidak lagi membiarkan peserta didik setelah lulus untuk mencari kerja sendiri karena dengan adanya surat pernyataan diawal tersebut maka pihak sekolah memiliki kewajiban mencarikan pekerjaan untuk calon lulusan dan alumninya.

Sekolah memilih anggota BKI yang berasal dari background guru produktif. Hal ini dimaksudkan karena orang-orang produktif lebih mengerti dan lebih mampu menempatkan dan mencarikan lowongan pekerjaan sesuai dengan jurusan atau kemampuan peserta didiknya. Menurut pihak BKI dengan adanya penempatan anggota yang sesuai maka akan mempercepat pemasaran lulusan. Selain BKI berkoordinasi dengan kepala bidang dan juga guru- guru yang memang mengasah kemampuan mereka selain dengan pelajaran-pelajaran produktif, normatif, dan adaptif. Tim BKI sangat dibantu dengan adanya guru wali yang menangani mereka dari mulai masuk sekolah sampai menjadi alumni. Guru wali adalah guruguru yang menjadi pembimbing mereka selama sekolah. Guru wali semacam guru Pembimbing Akademik (PA) jika diposisikan di Perguruan Tinggi karena di sekolah tidak ada wali kelas maka jika beberapa peserta didik pindah kelas maka guru wali mereka tetaplah sama. Berdasarkan uraian tersebut dapat disimpulkan bahwa pengorganisasian pemasaran lulusan ditangani oleh kepala sekolah sebagai penanggung jawab dan dibantu oleh tim BKI, kepala bidang jurusan, dan guru wali dalam melaksanakan pemasaran lulusan sehingga peserta didik mudah terserap ke dunia kerja.

\subsubsection{Pelaksanaan Pemasaran Lulusan dalam Satuan Pendidikan Kejuruan}

Pemasaran memang dilakukan sebelum mereka lulus sehingga saat mereka sudah lulus sudah banyak yang mendapatkan pekerjaan. Tak jarang saat peserta didik selesai prakerin juga langsung direkrut oleh perusahaan tempatnya prakerin karena memang kinerjanya yang cukup memenuhi kriteria perusahaan. Bahkan untuk peserta didik yang sudah menjadi alumni masih mendapatkan pantauan selama 1 tahun dari pihak BKI untuk tetap mendapatkan pekerjaan. Rekrutmen yang dilakukan sekolah sangat efektif karena sekolah berusaha semaksimal mungkin untuk bekerjasama dengan banyak mitra kerja yang nantinya bisa melakukan perekrutan peserta didik lebih banyak. Perekrutan yang dilakukan oleh perusahaan biasanya dilakukan di sekolah atau di perusahaan tersebut. Tetapi tak jarang melakukan rekrutmen di sekolah lain jika diperlukan atau memang ada rekrutmen yang 
dicampur dengan peserta didik sekolah lain. Tetapi jika pihak perusahaan hanya meminta peserta didik kelas 12 dan alumni saja, maka rekrutmen dilakukan di sekolah. Kadang pihak perusahaan meminta karyawan dengan jumlah yang banyak dan minta diinformasikan ke sekolah-sekolah lain maka sekolah akan menginformasikan lowongan pekerjaan tersebut.

Kepala sekolah menargetkan $60 \%$ dari total peserta didik kelas 12 harus sudah mendapatkan pekerjaan sebelum Ujian Nasional berlangsung. Akan tetapi pihak BKI hanya mencapai target $40-50 \%$ peserta didik sudah mendapatkan pekerjaan sebelum mereka Ujian Nasional. Angka tersebut sudah lumayan bagus karena sudah mendekati dari angka yang ditargetkan oleh kepala sekolah. Sedangkan untuk peserta didik yang belum memperoleh pekerjaan sebelum Ujian Nasional mereka masih banyak kesempatan karena pihak sekolah akan membuatkan daftar lowongan pekerjaan pasca UNBK. Daftar lowongan pekerjaan pasca UNBK untuk mempermudah calon alumni untuk memilah-milah perusahaan dan posisi yang tepat dengan kemampuan atau keahlian mereka. Peserta didik yang mengikuti rekrutmen kerja pasca UNBK akan bersamaan dengan ujian praktek sekolah. Jika peserta didik pada hari itu melakukan rekrutmen kerja diluar sekolah atau ditempat perusahaan yang melakukan rekrutmen maka biasanya mereka akan kembali ke sekolah untuk melaksanakan ujian praktek sekolah ataupun hanya sekedar mengetahui informasi-informasi yang ada di sekolah. Berdasarkan uraian tersebut dapat disimpulkan bahwa pelaksanaan pemasaran lulusan adalah dengan membentuk kelas industri, melakukan rekrutmen kerja, dan melakukan rekrutmen kerja setelah prakerin sehingga peserta didik banyak yang terserap ke dunia kerja karena sebelum mereka lulus sudah memperoleh pekerjaan.

\subsubsection{Evaluasi Pemasaran Lulusan dalam Satuan Pendidikan Kejuruan}

Evaluasi merupakan tahap apakah kegiatan-kegiatan yang sudah direncanakan di awal sudah berjalan dengan baik atau belum. Evaluasi dilakukan untuk mengetahui tingkat keberhasilan suatu kegiatan yang sudah direncanakan sebelumnya. Apabila dalam melakukan evaluasi kegiatan yang telah direncanakan hasilnya sudah cukup maksimal maka akan dipertahankan atau lebih ditingkatkan lagi. Evaluasi pemasaran lulusan yang dilakukan sekolah adalah kegiatan penelusuran lulusan dan pemberian informasi lowongan pekerjaan kepada alumni. Penelusuran lulusan merupakan cara sekolah untuk mengetahui bagaimana keberhasilan sekolah dalam memasarkan lulusannya. Jika masih banyak alumni yang belum memiliki kerja atau belum direkrut oleh perusahaan-perusahaan rekanan sekolah ataupun bukan, maka kinerja dari BKI untuk memasarkan lulusannya dikatakan kurang berhasil. Sebaliknya, apabila banyak alumni yang sudah bekerja atau direkrut oleh perusahaan maka kinerja dari BKI bisa dikatakan cukup berhasil. Penelusuran lulusan menjadi salah satu bahan evaluasi pemasaran lulusan yang mana hasil dari penelusuran tersebut dijadikan bahan oleh pihak BKI untuk mengetahui apakah peserta didiknya setelah lulus memiliki angka keterserapan kerjanya tinggi atau masih rendah.

Angka keterserapan kerja dihitung sejak 1 tahun mereka lulus karena masih masa pantau dari pihak sekolah memang tidak $100 \%$ bekerja dari 831 peserta didik tetapi sudah mencapai angka yang cukup tinggi antara $80-90 \%$ yaitu 821 peserta didik yang lulus tahun 2018 karena memang masih ada saja alumni yang susah untuk dicari dan dihubungi. Cara sekolah untuk menginformasikan lowongan-lowongan pekerjaan untuk alumni sangat efektif dan efisien. Pihak BKI menggunakan media sosial untuk melakukan penyebaran informasi lowongan kerja kepada alumni. Di era sekarang, alumni dan pihak sekolah memang 
dipermudah dengan adanya teknologi. Pihak sekolah menyebarkan informasi lowongan pekerjaan menggunakan media whatsApp, instagram, dan facebook. Mereka juga memiliki grup per jurusan dan per angkatan yang akan mempermudah tim BKI untuk menginformasikan lowongan pekerjaan. Alumni yang masih dimonitoring oleh sekolah setelah lulus dalam kurun waktu 1 tahun yang akan mengikuti rekrutmen kerja atau tes seleksi harus melakukan konfirmasi kepada pihak BKI. Konfirmasi dimaksudkan agar tim BKI mengetahui berapa peserta didiknya yang masih belum diterima kerja. Karena ada perjanjian yang terikat dalam surat pernyataan yang telah ditandatangani sebelumnya maka sekolah berusaha mencarikan peserta didik pekerjaan sampai dengan waktu 1 tahun setelah peserta didik lulus. Berdasarkan uraian tersebut dapat disimpulkan bahwa evaluasi pemasaran lulusan adalah melakukan penelusuran lulusan sehingga pihak sekolah mengetahui tingkat keterserapan lulusan. Selanjutnya, melakukan penyebaran lowongan pekerjaan karena ketika pihak sekolah menyebarluaskan lowongan pekerjaan peserta didik akan konfirmasi kepada tim BKI sehingga berapa banyak lulusan yang sudah dan belum memperoleh pekerjaan.

\subsubsection{Faktor Mendukung dan Menghambat Pemasaran Lulusan}

Suatu kegiatan atau program dikatakan berhasil dapat dilihat dari manajemen dan fungsi- fungsinya. Terdapat pula faktor yang mendukung dan faktor yang menghambat dalam menjalankan suatu program atau kegiatan. Faktor yang mendukung dalam suatu program biasanya berupa kelebihan atau kekuatan, sedangkan faktor yang menghambat biasanya berupa kekurangan atau kelemahan. Dalam manajemen pemasaran lulusan terdapat beberapa faktor yang mendukung dalam pelaksanaan kegiatan tersebut, tetapi ada juga faktor yang menghambat dalam pelaksanaan kegiatan tersebut. Faktor- faktor tersebut berupa a) produk (lulusan); b) penetapan harga; c) promosi; d) distribusi; e) orang/SDM; f) bukti fisik; g) proses, dan h) layanan pelanggan. Kedelapan faktor yang mendukung dalam pemasaran lulusan ini dapat menjadi faktor yang menghambat pemasaran lulusan apabila dalam menjalankan kegiatan pemasaran lulusan kurang berjalan maksimal. Sedangkan untuk faktor yang menghambat pemasaran lulusan hanya terdapat pada orangtua. Orangtua menginginkan anaknya untuk tidak bekerja di daerah yang jauh padahal di Malang bukan kawasan industri, sehingga solusinya orangtua didatangkan ke sekolah dan diberi arahan oleh tim BKI dan sedikit menekan jika memang tetap tidak ingin anaknya ditempatkan kerja yang jauh. Berdasarkan uraian tersebut dapat disimpulkan bahwa faktor yang mendukung pemasaran lulusan yaitu dari lulusan, harga, promosi, distribusi, SDM, bukti fisik, proses dan layanan pelanggan. Adapan faktor penghambatnya dari sisi orangtua yang tidak ingin anaknya kerja ditempat yang jauh. Berdasarkan hasil penelitian dapat disajikan bagan sebagai berikut: 


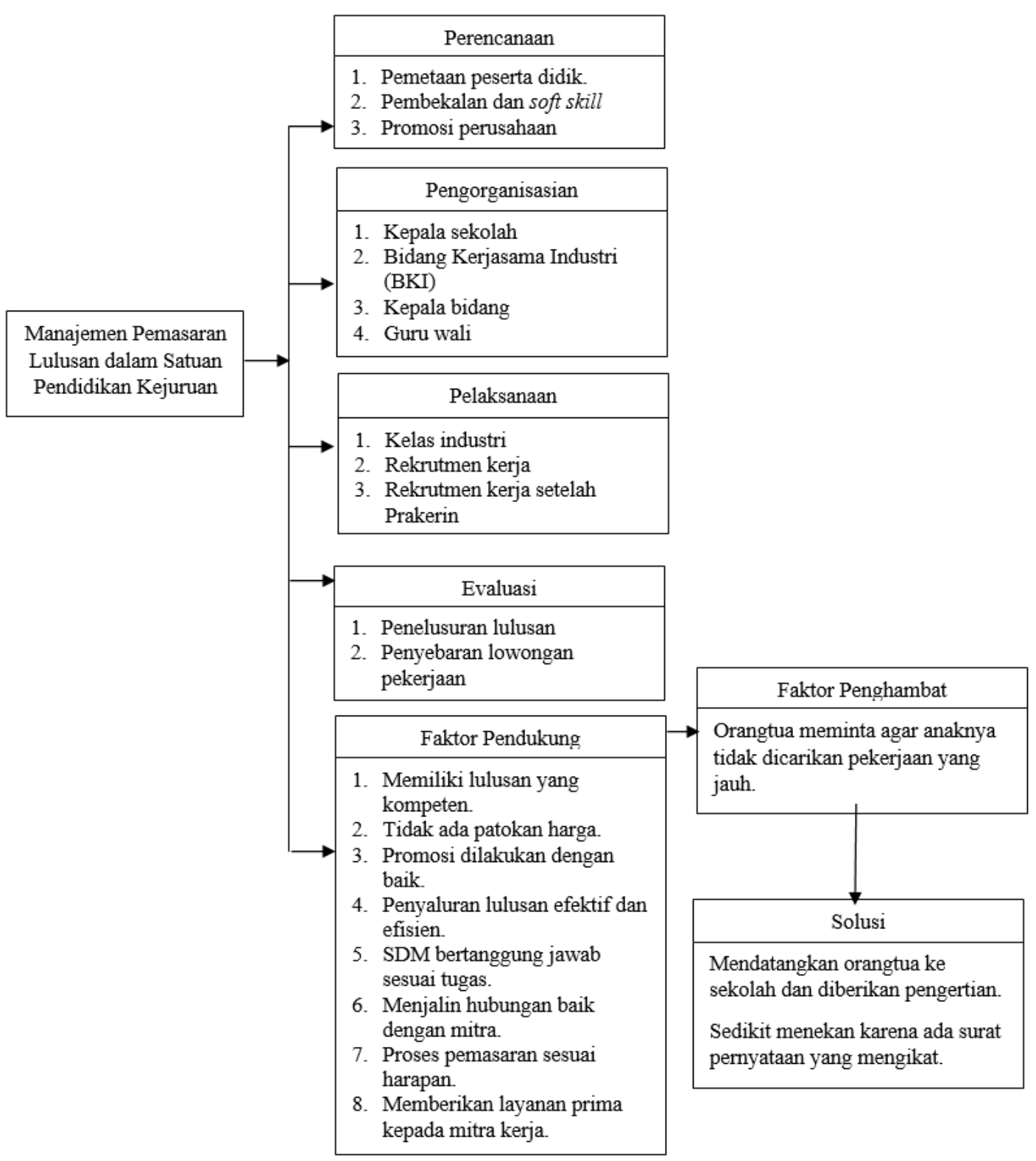

Gambar 1. Bagan Hasil Penelitian Keseluruhan

Berdasarkan hasil penelitian keseluruhan dapat disimpulkan bahwa manajemen pemasaran lulusan dalam satuan pendidikan adalah perencanaan yaitu pemetaan peserta didik, pembekalan, promosi ke perusahaan. Pengorganisasian meliputi kepala sekolah, tim BKI, kepala bidang, dan guru wali. Pelaksanaan adalah kelas industry, rekrutmen kerja, rekrutmen kerja setelah prakerin. Evaluasi meliputi penelusuran lulusan dan penyebaran lowongan pekerjaan. Faktor yang mendukung adalah lulusan, tidak ada patokan harga, promosi, penyaluran, SDM, hubungan yang baik, proses pemasaran, dan layangan prima. Faktor penghambatnya adalah orangtua tidak ingin anaknya bekerja jauh, sedangkan solusinya adalah memberikan arahan dan pengertian kepada orangtua. 


\subsection{Pembahasan}

\subsubsection{Perencanaan Pemasaran Lulusan dalam Satuan Pendidikan Kejuruan}

Perencanaan pemasaran lulusan dalam mempercepat penyerapan lulusan dalam dunia kerja yaitu dengan melakukan pemetaan atau pengklasifikasian peserta didik setelah mereka lulus dari sekolah. Pengklasifikasian dilakukan di awal kelas 3 dengan memilih apakah peserta didik ketika lulus akan bekerja, masuk kuliah, masuk TNI/Polri, atau berwirausaha yang ada dalam surat pernyataan. Kegiatan perencanaan merupakan proses penyusunan program atau kegiatan yang akan dilakukan di masa yang akan datang. Dengan tujuan agar program tersebut berjalan berurutan dan sistematis sesuai dengan tujuan yang telah disepakati bersama oleh anggotanya (Usman, 2015). Suatu rencana memungkinkan bahwa sebuah organisasi dapat menjalankan suatu tujuan organisasi secara konsisten yang telah disepakati bersama (Saondi, 2014). Dalam merencanakan pemasaran lulusan di sekolah, pihak BKI berusaha maksimal agar program yang dibuat dalam merencanakan pemasaran lulusan akan berhasil. Dengan adanya pemetaan peserta didik setelah mereka lulus maka pihak BKI lebih mudah dalam memberikan pembekalan yang tepat untuk peserta didik. Berdasarkan penjelasan tersebut dapat disimpulkan bahwa perencanaan pemasaran lulusan adalah kegiatan yang dilakukan untuk masa yang akan datang dan dilakukan secara konsisten. Kegiatan tersebut adalah dengan melakukan mengklasifikasian kepada peserta didik untuk memilih pilihannya setelah mereka lulus sekolah.

Kedua, pelatihan soft skill peserta didik dan pembekalan setelah mengisi surat pernyataan tersebut. Bagi peserta didik yang memilih melanjutkan kerja akan diberikan pembekalan berupa bagaimana cara membuat surat lamaran kerja yang baik, cara membuat curriculum vitae yang baik, cara menghadapi interview. Pembekalan-pembekalan seperti ini mungkin didapat oleh semua peserta didik pada saat pembelajaran berlangsung di kelas, tetapi pada pembekalan setelah memilih pilihan seperti dipelajari kembali pelajaran-pelajaran tersebut. Bagi yang memilih melanjutkan kuliah akan diberi pembekalan bagaimana cara menembus SNMPTN, SBMPTN. Bagi yang melanjutkan berwirausaha, sekolah mendapatkan bantuan dari Dinas Sosial untuk menyelenggarakan seminar pelatihan berwirausaha. Soft skill merupakan kemampuan yang dimiliki seorang individu yang tidak terlihat dan dapat dikembangkan dengan melalui pelatihan yang baik. Soft skill dapat berupa ekspresi wajah, sopan santun, cara bicara, cara duduk, dan lain sebagainya (Turistiati, 2019). Berdasarkan uraian tersebut pembekalan dan pelatihan soft skill untuk calon lulusan sangat diperlukan. Dalam memasuki dunia kerja atau melakukan rekrutmen kerja maka calon pegawai akan dilihat bagaimana soft skill mereka sehingga menjadi pertimbangan dari perusahaan untuk mempekerjakan mereka.

Ketiga, sekolah melakukan promosi kepada perusahaan- perusahaan mitra kerja sekolah. Promosi ini dilakukan sedini mungkin dengan harapan sebelum Ujian Nasional berlangsung peserta didik sudah harus mendapatkan pekerjaan. Promosi dilakukan dengan mendatangkan perusahaan- perusahaan ke sekolah dan pihak dari perusahaan akan memilih sendiri peserta didik yang akan dijadikan karyawan di perusahaan tersebut. Dalam konteks pendidikan adalah memasarkan lulusannya agar mudah diserap oleh mitra kerja rekanan sekolah (Indradjaja \& Karno dalam Wijaya: 2012). Sedangkan menurut Mundir (2016) pemasaran pendidikan merupakan kegiatan yang dilakukan oleh lembaga pendidikan dalam memasarkan dan mempromosikan hal- hal yang ada di dalam sekolah. 
Tim BKI akan berusaha mencarikan pekerjaan kepada calon lulusannya karena mereka sudah terikat semacam surat perjanjian yang berupa surat pernyataan pilihan ketika peserta didik lulus. Bahkan dalam kurun waktu 1 tahun setelah mereka lulus maka tim BKI akan tetap memantau alumninya agar keterserapan alumni semakin banyak. Berdasarkan uraian diatas promosi yang dilakukan sekolah kepada mitra kerja rekanan sekolah agar lulusan mudah terserap ke dunia kerja dilakukan dengan maksimal sehingga banyak lulusan yang sudah memperoleh pekerjaan sebelum mereka lulus.

\subsubsection{Pengorganisasian Pemasaran Lulusan dalam Satuan Pendidikan Kejuruan}

Suatu lembaga membutuhkan struktur organisasi agar anggota mengetahui secara jelas apa saja tugas dan tanggung jawabnya. Struktur dalam organisasi mempermudah dalam melakukan kegiatan atau program yang akan dilaksanakan karena telah disepakati bersama. Pembinanya adalah Kepala Dinas Tenaga Kerja dan Transmigrasi (Disnakertrans) Malang, penanggungjawab BKI adalah kepala sekolah, kemudian ketua BKI dilanjutkan dengan 6 stafnya, dan terakhir adalah pencari kerja yaitu peserta didik SMK PGRI 3 Kota Malang. Suatu lembaga membutuhkan organisasi yang sudah terstruktur dengan baik dengan dilengkapi tugas dan tanggung jawabnya. Adanya organisasi yang terstruktur mempermudah dalam melaksanakan perencanaan yang telah disepakati bersama. Berdasarkan temuan penelitian dalam pemasaran lulusan, sumber daya manusia yang paling berpengaruh dan paling menangani terkait dengan pemasaran lulusan adalah tim Bidang Kerjasama Industri (BKI) dengan kepala sekolah yang menjadi penanggung jawabnya dengan dibantu oleh kepala jurusan dan guru wali.

Kegiatan pengorganisasian merupakan pembagian tugas kepada anggotanya dan membebankan tugas kepada orang yang sesuai dengan keahliannya untuk mencapai tujuan organisasi (Fattah, 2013). Fungsi pengorganisasian adalah penyusunan kegiatan organisasi sesuai dengan tujuan dari organisasi dan juga memberdayakan sumber daya manusia yang memiliki kemampuan sesuai dengan program yang akan dilaksanakan sehingga dapat memperoleh hasil yang maksimal (Usman, 2013). Kegiatan pengorganisasian adalah cara organisasi merencanakan struktur organisasinya agar posisi yang dalam struktur tersebut sesuai dengan tugas dan fungsi sehingga memiliki tanggung jawab yang penuh (Kompri, 2015). Bursa Kerja Khusus (BKK) merupakan suatu tim atau bursa kerja yang ada di sekolah menengah kejuruan yang bertugas untuk mencarikan pasar kerja kepada peserta didiknya, melakukan pendaftaran kerja, dan membantu menyalurkan pencari kerja (Hermansyah, 2009). Pengorganisasian pemasaran lulusan ditangani oleh tim BKI yang dibentuk oleh kepala sekolah yang bertugas menangani pemasaran peserta didik sebelum atau sesudah mereka lulus dari sekolah, menangani penempatan prakerin peserta didik, dan mencarikan kerjasama dengan perusahaan- perusahaan sehingga calon alumni dan alumninya mudah terserap ke dunia kerja. Tim BKI juga diberdayakan dari orang- orang produktif karena orang- orang produktif akan lebih mengerti pekerjaan- pekerjaan yang cocok untuk jurusan dan kemampuan peserta didiknya. Dengan adanya sumber daya manusia yang tepat maka pemasaran lulusan juga akan terserap secara maksimal.

Berdasarkan uraian diatas pengorganisasian pemasaran lulusan ditangani oleh tim BKI yang dibentuk oleh kepala sekolah yang bertugas menangani pemasaran peserta didik sebelum atau sesudah mereka lulus dari sekolah, menangani penempatan prakerin peserta didik, dan 
mencarikan kerjasama dengan perusahaan- perusahaan sehingga calon alumni dan alumninya mudah terserap ke dunia kerja.

\subsubsection{Pelaksanaan Pemasaran Lulusan dalam Satuan Pendidikan Kejuruan}

Fungsi pelaksanaan didukung oleh sumber daya dan fasilitas yang dalam kegiatan tersebut sehingga kerjasama antara anggota dapat tercapai (Kurniadi \& Machali, 2013). Pelaksanaan kegiatan adalah penggerakan sumber daya yang ada agar anggota- anggota organisasi berkeinginan untuk mencapai tujuan atau sasaran yang telah disepakati bersama pada awal perencanaan. Sasaran dan tujuan akan mudah tercapai jika ada koordinasi yang baik antar anggota organisasi (Terry dalam Suharsaputra, 2013). Kegiatan atau program pelaksanaan pemasaran lulusan sebagai upaya mempercepat penyerapan lulusan dalam dunia kerja di sekolah adalah bentuk realisasi dari perencanaan yang telah dibuat oleh tim BKI sekolah. Kegiatan pelaksanaan pemasaran lulusan dengan membentuk kelas- kelas industri, pembentukan kelas industri adalah bentuk kerjasama yang dilakukan oleh sekolah dengan suatu perusahaan untuk membentuk sebuah kelas industri. Kegiatan pelaksanaan dalam pemasaran lulusan adalah bentuk realisasi dari perencanaan yang telah dibuat dan ditetapkan sebelumnya. Adapun kegiatan pelaksanaan dalam pemasaran lulusan di SMK PGRI 3 Kota Malang adalah membuat kelas- kelas industri, kelas industri adalah kelas yang dibuat atas kerjasama dari perusahaan dengan sekolah. Kelas industri merupakan kelas khusus yang dibuat agar pemasaran di sekolah semakin efektif karena peserta didik yang masuk kedalam kelas industri maka setelah mereka lulus dari sekolah mereka akan langsung direkrut oleh perusahaan yang membuat kelas industri tersebut; Pembentukan kelas industri berperan untuk mempercepat penyerapan lulusan untuk masuk dunia kerja karena kurikulum yang diajarkan di kelas industri adalah campuran dari kurikulum sekolah dan kurikulum dari perusahaan. Kelas industri merupakan suatu kelas yang dibentuk antara kerjasama sekolah dan industri dengan menyatukan sistem yang ada di sekolah dengan sistem perusahaan yang bersangkutan sehingga menciptakan lulusan yang memiliki kompetensi dan kemampuan yang sudah menjadi target perusahaan tersebut (Slamet, dkk, 2017). Kelas industri dapat mempercepat penyerapan lulusan untuk masuk dunia kerja karena dengan adanya kelas industri yang menggabungkan antara kurikulum sekolah dan kurikulum perusahaan akan menjadikan lulusan memiliki kemampuan yang sesuai dengan harapan perusahaan.

Rekrutmen kerja yang dilakukan sekolah dilaksanakan sebelum mereka lulus dari sekolah. Setelah mengisi surat pernyataan mengenai pilihan peserta didik setelah lulus maka sekolah akan segera mengundang perusahaan- perusahaan untuk datang ke sekolah dan memilih sendiri peserta didik yang sesuai dengan kebutuhan dari perusahaan tersebut. Rekrutmen biasanya dilaksanakan di aula sekolah tetapi kadang juga dilaksanakan di perusahaan tersebut. Kegiatan rekrutmen kerja merupakan kegiatan mencari pelamar dan menemukan pelamar untuk dijadikan pegawai ke dalam suatu organisasi yang membutuhkan pekerjaan dan memikat para pelamar dengan motivasi dan kemampuan (Sulistiyani \& Rosidah, 2009). Kemudian rekrutmen setelah prakerin, peserta didik yang selesai melakukan prakerin biasanya ditawari untuk menjadi karyawan di perusahaan tersebut. Tentunya arena kompetensi dan keterampilan dari peserta didik tersebut cukup unggul dan berkembang dilihat pada saat prakerin berlangsung. Cara rekrutmen melalui prakerin ini sangat efektif untuk sekolah dalam memasarkan lulusannya karena dengan begitu sebelum mereka Ujian Nasional sudah memperoleh pekerjaan sehingga target yang ditetapkan oleh sekolah akan bisa dicapai. Rekrutmen kerja setelah prakerin juga mempercepat penyerapan lulusan dalam dunia 
kerja karena dengan program prakerin yang dilakukan 1 tahun oleh sekolah membuat peserta didik prakerin lebih matang saat melakukan magang di suatu perusahaan. Praktek kerja industri merupakan bagian dari program sekolah yang wajib dilakukan oleh peserta didik untuk mengembangkan program dari SMK (Depdiknas, 2008). Sesuai dengan pendapat Hamalik (2007) tujuan dari praktek kerja industri adalah bagian dari proses latihan untuk mengembangkan keterampilan yang sudah didapat pada saat di sekolah.

Berdasarkan uraian dapat disimpulkan bahwa pelaksanaan pemasaran lulusan dengan membentuk kelas industri, rekrutmen kerja, dan rekrutmen kerja setelah prakerin akan mempermudah penyerapan lulusan dalam dunia kerja.

\subsubsection{Evaluasi Pemasaran Lulusan dalam Satuan Pendidikan Kejuruan}

Evaluasi pemasaran lulusan sebagai upaya mempercepat penyerapan lulusan dalam dunia kerja adalah dengan adanya penelusuran lulusan dan penyebaran lowongan pekerjaan kepada alumni yang masih dalam monitoring tim BKI. Evaluasi kegiatan merupakan suatu kegiatan yang dilakukan untuk mengetahui apakah program yang telah direncanakan sudah berhasil atau belum. Evaluasi memberikan kepastian terhadap suatu kegiatan yang mana kegiatan tersebut harus dilakukan evaluasi untuk mengetahui secara pasti rencana yang disepakati semula berjalan dengan baik (LANRI dalan Usman, 2013). Dalam evaluasi pemasaran lulusan dengan memberikan informasi lowongan pekerjaan kepada alumni. Hal ini memberikan informasi kepada BKI mengenai apakah alumni sudah memperoleh pekerjaan atau belum karena setiap tim BKI memberikan informasi kepada alumni yang masih dalam monitoring 1 tahun setelah mereka lulus, maka tim BKI mewajibkan alumni untuk konfirmasi kepada tim BKI agar sekolah dapat mengetahui berapakah alumni yang masih belum memperoleh pekerjaan. Penyebaran lowongan pekerjaan sangat dibutuhkan karena informasi dari dunia kerja yang berhubungan dengan ketenagakerjaan yang berasal dari sumber baik cetak maupun elektronik akan dapat mempengaruhi evaluasi dari keterserapan alumni dalam suatu sekolah (Kulut, 2014). Penyebaran lowongan kerja pada grup- grup alumni juga membantu tim BKI untuk mengetahui masih seberapa peserta didik yang belum bekerja, karena setelah BKI mengirim lowongan pekerjaan ke alumni maka BKI meminta agar alumni tersebut melakukan konfirmasi dengan BKI. Dari situ tim BKI mengetahui bahwa anak tersebut belum memperoleh pekerjaan dan tim BKI akan membantu karena memang pihak sekolah harus tetap mencarikan pekerjaan kepada alumninya dengan kurun waktu 1 tahun setelah mereka lulus karena sekolah diikat oleh surat pernyataan yang ditandatangani pada saat awal perencanaan

Penelusuran lulusan dilakukan untuk mengetahui seberapa banyak alumni dari sekolah yang sudah bekerja atau yang belum bekerja. Penelusuran lulusan ini menjadi bahan evaluasi untuk tim BKK dalam memperbaiki perencanaan- perencanaan yang dibuat sebelumnya. Jika banyak lulusan yang bekerja dihitung dalam waktu 1 tahun setelah lulus maka program dari tim BKI berjalan cukup baik. Namun jika sebaliknya maka perencanaan yang telah ditetapkan kurang berjalan maksimal. Penelusuran lulusan adalah bentuk aktivitas untuk mengetahui apakah lulusan sudah memperoleh pekerjaan atau belum. Penelusuran lulusan sangat bermanfaat untuk sekolah karena hasil dari penelusuran lulusan akan menjadi bahan evaluasi untuk sekolah (Wuradji, 2010). Penelusuran lulusan merupakan kegiatan menelusuri atau mencari tahu keberadaan alumninya mengenai apakah alumni tersebut sudah memperoleh pekerjaan atau masih menganggur. Di SMK PGRI 3 Kota hasil dari penelusuran lulusan akan 
menjadi bahan untuk sekolah dalam melakukan proses evaluasi pemasaran lulusan. Proses evaluasi pemasaran lulusan dimaksudkan agar program yang telah disepakati bersama sudah berhasil ataukah harus diperbaiki lagi.

\subsubsection{Faktor Mendukung dan Menghambat Pemasaran Lulusan}

Selain adanya fungsi-fungsi manajemen pemasaran lulusan mulai dari perencanaan, pengorganisasian, pelaksanaan, dan evaluasi. Terdapat juga faktor yang mendukung dan faktor yang menghambat manajemen pemasaran lulusan sebagai upaya mempercepat penyerapan lulusan dalam dunia kerja. Di sekolah terdapat faktor yang mendukung diantaranya adalah memiliki lulusan yang kompeten, tidak ada patokan harga, promosi dilakukan dengan baik, penyaluran lulusan yang efektif dan efisien, SDM bertanggung jawab sesuai dengan tugas, menjalin hubungan baik dengan mitra, proses pemasaran sesuai dengan harapan, dan memberikan layanan prima kepada mitra kerja. Faktor yang menghambat manajemen pemasaran lulusan dapat dilihat dari bauran pemasaran apabila poin- poin dalam bauran pemasaran yang menjadi faktor pendukung terhambat atau berjalan kurang maksimal. Bauran pemasaran jasa pendidikan adalah elemen- elemen yang dapat diukur dan dikontrol oleh organisasi agar menjadi faktor yang mendukung suatu manajemen pemasaran. Bauran pemasaran meliputi produk, harga, lokasi, promosi, orang, bukti fisik, dan proses (Alma dan Hurriyati dalam Benty dan Gunawan, 2015). Faktor yang mendukung pemasaran lulusan dilihat dari bauran pemasaran sebagai berikut: (1) lulusan, lulusan dari sekolah harus memiliki kompetensi yang baik; (2) harga, sebaiknya tidak ada patokan harga dalam setiap kegiatan; (3) promosi, promosi yang dilakukan oleh sekolah harus dilakukan secara baik dan menarik; (4) distribusi, penyaluran lulusan harus secara efektif dan efisien misalnya berhubungan dengan jarak atau citra sekolah; (5) sumber daya manusia, SDM yang diperlukan untuk pemasaran lulusan harus bertanggung jawab terhadap tugasnya; (6) bukti fisik, bukti fisik berhubungan dengan bagaimana pihak sekolah menjalin hubungan yang baik dengan mitra kerja; (7) proses, proses pemasaran diharapkan sesuai dengan yang diinginkan; dan (8) layanan, pihak sekolah memberikan layanan prima terhadap perusahaan- perusahaan rekanan sekolah (Tjiptono, 2011).

Sedangkan untuk faktor yang menghambat manajemen pemasaran lulusan adalah dari segi orangtua karena ada sebagian orang tua peserta didik yang tidak menginginkan anaknya untuk bekerja ditempat yang jauh. Solusi yang dilakukan sekolah adalah dengan mendatangkan orangtua ke sekolah untuk diberikan pengertian dan arahan agar mengijinkan anaknya untuk kerja sesuai dengan dimana perusahaan menempatkan mereka kerja. Apabila cara tersebut dirasa belum meyakinkan orangtua maka pihak BKI sedikit menekan orangtua peserta didik karena jika orangtua tetap tidak mengijinkan anaknya untuk bekerja di tempat yang jauh maka pihak sekolah sudah selesai melakukan tugasnya untuk mencarikan peserta didiknya kerja karena memang sekolah terikat dengan surat pernyataan yang sebelumnya sudah diisi. Dikarenakan memang pihak sekolah ada kewajiban mencarikan kerja maka ketika peserta didik sudah mendapatkan pekerjaan dan ternyata peserta didik atau orangtua peserta didik tidak bersedia maka tugas tim BKI sudah selesai dalam mencarikan pekerjaan peserta didiknya.

\section{Simpulan}

Berdasarkan temuan penelitian dan pembahasan mengenai manajemen pemasaran lulusan di SMK PGRI 3 Kota Malang, maka dapat disimpulkan: (1) perencanaan pemasaran 
lulusan dalam satuan pendidikan kejuruan adalah dengan melakukan pemetaan peserta didik sesuai pilihan peserta didik setelah mereka lulus yaitu memilih bekerja, masuk kuliah, masuk TNI/Polri, dan berwirausaha. Selanjutnya, dengan memberikan pelatihan soft skill dan pembekalan kepada peserta didik sehingga setelah mereka lulus siap bekerja di perusahaanperusahaan rekanan sekolah. Selain itu, tim BKI melakukan promosi kepada perusahaan yang bekerjasama dengan sekolah untuk mengetahui apakah ada lowongan pekerjaan untuk calon alumni dan alumni; (2) pengorganisasian pemasaran lulusan dalam satuan pendidikan kejuruan adalah dengan adanya BKI dibawah tanggung jawab kepala sekolah. Serta dibantu oleh kepala bidang per jurusan dan guru wali yang sudah mengerti karakteristik perwaliannya; (3) pelaksanaan pemasaran lulusan dalam satuan menengah kejuruan adalah membuat kelas industri yang dibentuk antara kerjasama sekolah dengan perusahaan. Selanjutnya melakukan rekrutmen kerja yang dilaksanakan sedini mungkin agar sebelum peserta didik lulus sekolah sudah memperoleh pekerjaan. Selain itu, melakukan rekrutmen kerja setelah prakerin agar peserta didik yang harus dicarikan pekerjaan semakin sedikit; (4) evaluasi pemasaran lulusan dalam satuan pendidikan kejuruan adalah melakukan penelusuran lulusan sehingga tim BKI mengetahui seberapa banyak alumni yang masih belum memperoleh pekerjaan. Selain itu, memberikan informasi lowongan pekerjaan kepada alumni karena alumni yang masih dalam masa monitoring 1 tahun ketika tim BKI menyebarkan lowongan pekerjaan harus melakukan konfirmasi kepada tim BKI apabila tertarik untuk melamar pekerjaan tersebut; dan (5) faktorfaktor yang mendukung dan menghambat pemasaran lulusan adalah dengan memiliki lulusan yang kompeten, tidak ada patokan harga, promosi dilakukan dengan baik, penyaluran lulusan yang efektif dan efisien, SDM bertanggung jawab sesuai dengan tugas, menjalin hubungan baik dengan mitra, proses pemasaran sesuai dengan harapan, dan memberikan layanan prima kepada mitra kerja, sedangkan untuk faktor yang menghambat manajemen pemasaran lulusan adalah ketika orangtua tidak memberikan izin kepada anaknya untuk bekerja di tempat yang jauh. Solusinya adalah tim BKI memberikan pengertian dan arahan kepada orangtua apabila masih tidak berhasil maka tim BKI sedikit menekan agar anaknya diperbolehkan kerja di tempat yang sudah diatur oleh perusahaan.

\section{Daftar Rujukan}

Abdullah, T. \& Tantri, F. (2012). Manajemen Pemasaran. Jakarta: Rajawali Press.

Arifin, Z. (2019). Penyebab Lulusan SMA dan Perguruan Tinggi Dominasi Pengangguran di Malang, (Online), (https://www.liputan6.com/regional/read/3882748/penyebab-lulusan-sma-dan-perguruan-tinggidominasi-pengangguran-dimalang?related=dable\&utm_expid=.9Z4i5ypGQeGiS7w9arwTvQ.1\&utm_referrer=https\%3A\%2F\%2F www.google.com\%2F) diakses 7 Juli 2019.

Benty, D. D. N., \& Gunawan, I. (2015). Manajemen Hubungan Sekolah dan Masyarakat. Malang: Universitas Negeri Malang.

Departemen Pendidikan Nasional. (2008). Pelaksanaan Prakerin. Jakarta: Depdiknas RI

Fattah, N. (2013). Landasan Manajemen Pendidikan. Bandung: Remaja Rosdakarya.

Hamalik, O. (2007). Manajemen Pelatihan Ketenagakerjaan. Jakarta: Bumi Aksara.

Hermansyah. (2009). Manajemen Bursa Kerja Khusus (BKK) SMK. Yogyakarta: Paramita Publishing.

Kompri, (2015). Manajemen Pendidikan. Bandung: ALFABET.

Kulut, J. (2014). Kinerja Bursa Kerja Khusus (BKK) Dalam Penempatan Kerja Calon Lulusan Jurusan Teknik Bangunan SMK Negeri 3 Yogyakarta. Skripsi tidak diterbitkan.Yogyakarta: UNY.

Kurniadin, D \& Machali, I. (2013). Manajemen Pendidikan: Konsep \& Prinsip Pengelolaan Pendidikan. Yogyakarta: Ar-ruzz Utama.

Mundir, A. (2015). Strategi pemasaran jasa pendidikan madrasah. MALIA: Jurnal Ekonomi Islam, 7(1). 
Jurnal Pembelajaran, Bimbingan, dan Pengelolaan Pendidikan, 1(9), 2021, 718-731

Peraturan Pemerintah Nomor 19 Tahun 2005 Pasal 26 ayat 3 tentang Standar Nasional Pendidikan.

Rahardjo, R. S. (2012). Kualitas layanan bursa kerja khusus dan persepsi alumni smk se kabupaten kendal jawa tengah. Teknologi dan Kejuruan: Jurnal teknologi, Kejuruan dan Pengajarannya, 32(1).

Saharsaputra, U. (2013). Administrasi Pendidikan. Bandung: Refika Aditama.

Saondi, O. (2014). Membangun Manajemen Pendidikan Berbasis Sistem Informasi. Bandung: PT Refika Aditama

Slamet, M. A. (2017). Studi pengelolaan kelas Honda pada Program Keahlian Teknik Sepeda Motor di SMK Negeri 9 Malang (Doctoral dissertation, Universitas Negeri Malang).

Sulistiyani, A \& Rosidah. (2009). Manajemen Sumber Daya Manusia. Yogyakarta: Graha Ilmu.

Tjiptono, F. (2011). Pemasaran Jasa. Jawa Timur: Banyumedia Publishing.

Turistiati, A. T., \& Ramadhan, H. F. A. (2019). Pelatihan Soft Skills Dan Pendampingan Siswa-Siswi SMK Di Kota Bogor Untuk Persiapan Memasuki Dunia Kerja. Jurnal Komunitas: Jurnal Pengabdian kepada Masyarakat, 1(2), 1-8.

Usman, H. (2013). Manajemen: Teori, Praktik, dan Riset Pendidikan. Jakarta: Bumi Aksara.

Wiyaja, D. (2012). Pemasaran Jasa Pendidikan. Jakarta; Salemba Empat.

Wuradji, M. \& Alip, M. (2010). Studi Penelusuran Lulusan Program Studi Manajemen Pendidikan Program Pascasarjana Universitas Negeri Yogyakarta. Jurnal Laporan Penelitian. 